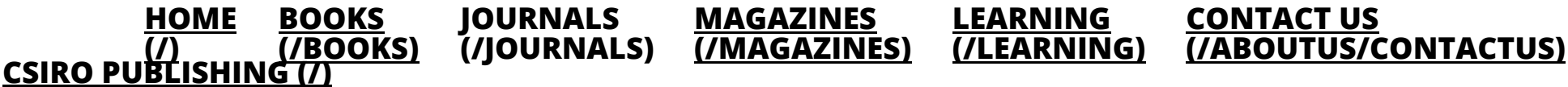 \\ show or hide menu items \\ WILDLIFE RESEARCH
}

(/wr)

Ecology, management and conservation in natural and modified habitats

Shopping Cart: ( empty) (/cart)

Search This Journal...

You are here: $\underline{\text { Home }(/)}>$ Lournals (/journals) $>\underline{\text { WR }(/ \mathrm{wr})}>$ WR13117

\section{Responses of phenology, synchrony and fecundity of breeding by African ungulates to interannual variation in rainfall}

Joseph O. Ogutu A B D , Hans-Peter Piepho ${ }^{B}$ and Holly T. Dublin C

A International Livestock Research Institute, PO Box 30709, Nairobi 00100, Kenya.

B University of Hohenheim, Institute for Crop Science, Bioinformatics Unit, 70599 Stuttgart, Germany.

C Species Survival Commission (SSC), The World Conservation Union (IUCN), c/o South African National Biodiversity Institute, Centre for Biodiversity Conservation, Private Bag X7, Claremont 7735, Cape Town, Republic of South Africa.

D Corresponding author. Email: jogutu2007@gmail.com (mailto:jogutu2007@gmail.com)

Wildlife Research 40(8) 698-717 http://dx.doi.org/10.1071/WR13117

Submitted: 25 June 2013 Accepted: 14 February 2014 Published: 20 March 2014

\section{Abstract}

Context: The timing and synchrony of births are important components of fitness among ungulates living in seasonal environments.
BUY PDF $\$ 25.00$

Supplementary

Material (8.8 MB)

(/wr/acc/WR13117/WR

Export

Citation

(http://www.publish.cs

\section{Subscriber Login}

Username:

Password: 
timing, synchrony and prolificity of births for six African ungulate species inhabiting an equatorial savanna with bimodal rainfall.

Methods: We analyse how seasonally and aseasonally breeding African savanna ungulates maintain reproductive success despite rainfall constraints, and adjust the phenology, synchrony and fecundity of their breeding to track interannual variation in rainfall. We use data on six ungulate species inhabiting the Masai Mara National Reserve (Mara) of Kenya to test five hypotheses concerning the influences of seasonality in resources, gestation length and the hider-follower strategy on the timing, synchrony and prolificity of calving.

Key results: Births were more synchronised for topi, warthog and zebra than for hartebeest, impala, and giraffe. Births occurred in most months, but tended to peak during the early rains when forage quality peaks for all species. The rainfall component exerting the strongest influence on timing of births varied with species. Gestation length, the hider-follower dichotomy, and hence predation, had apparently weak influences on birth synchrony. In drought years with nutritionally deficient forage, births were delayed, less synchronised and fewer. This portrayed protracted calving seasons, suppression of early conceptions, and delayed onset of births, calf losses, reproductive pauses or failures. However, in rainy years with sufficient forage, births peaked early, or were not delayed, and the synchronicity of calving increased for all species. This suggested early breeding by primiparous females; or higher fertility early in the mating period. The prolificity of calving increased with rainfall for topi and warthog but decreased for the remaining species.

Conclusions: Marked interannual variability in rainfall, plant phenology and forage sufficiency in tropical savannas impose strong constraints on ungulates, favouring flexible timing of births over strictly seasonal reproduction characteristic of temperate latitudes with predictable seasonal resource cues.

Implications: Despite high flexibility in their timing of births, widening rainfall variability expected to result from global warming could lower reproductive success of tropical ungulates by lowering their fecundity and survival prospects of their calves if droughts became more frequent and severe.

Additional keywords: rainfall variability, reproduction.

\section{References}

Adams, L. G., and Dale, B. W. (1998). Timing and synchrony of parturition in Alaskan caribou. Journal of Mammalogy 79, 287-294.

| CrossRef (http://dx.doi.org/10.2307/1382865) | (OpenURL BaseURL) 


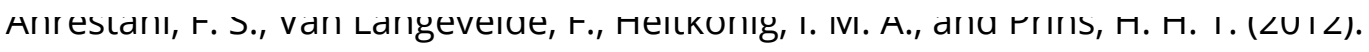
Contrasting timing of parturition of chital Axis axis and gaur Bos gaurus in tropical South India - the role of body mass and seasonal forage quality. Oikos 121, 1300-1310. | CrossRef (http://dx.doi.org/10.1111/j.1600-0706.2011.20244.x) | (OpenURL BaseURL)

Aitken, R. J. (1974). Delayed implantation in roe deer (Capreolus capreolus). Journal of Reproduction and Fertility 39, 225-233.

| CrossRef (http://dx.doi.org/10.1530/jrf.0.0390225) | CAS (http://chemport.cas.org/cgibin/sdcgi?APP=ftslink\&action=reflink\&origin=csiro\&version=1.0\&pissn=1035-

3712\&pyear=2014\&coi=1:STN:280:DyaE2c3pvF2rsw\%3D\%3D\&md5=876db29b723925300ba8b36d3db2ab20) | PubMed (http://www.ncbi.nlm.nih.gov/pubmed?

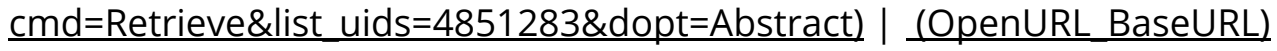

Albon, S. D., and Langvatn, R. (1992). Plant phenology and the benefits of migration in a temperate ungulate. Oikos 65, 502-513.

| CrossRef (http://dx.doi.org/10.2307/3545568) | (OpenURL BaseURL)

Albon, S. D., Mitchell, B., Huby, B. J., and Brown, D. (1986). Fertility in female red deer (Cervus elaphus): the effects of body composition, age and reproductive status. Journal of Zoology 209, 447-460.

| CrossRef (http://dx.doi.org/10.1111/j.1469-7998.1986.tb03603.x) | (OpenURL BaseURL)

Albon, S. D., Clutton-Brock, T. H., Major, M., and Guinness, F. E. (1987). Early development and population dynamics in red deer. II. Density-independent effects and cohort variation. Journal of Animal Ecology 56, 69-81.

| CrossRef (http://dx.doi.org/10.2307/4800) | (OpenURL BaseURL)

Andersen, R., Gaillard, J.-M., Linnell, J. D. C., and Duncan, P. (2000). Factors affecting maternal care in an income breeder, the European roe deer. Journal of Animal Ecology 69, 672-682.

| CrossRef (http://dx.doi.org/10.1046/j.1365-2656.2000.00425.x) | (OpenURL BaseURL)

Baker, J. R. (1938). The evolution of breeding seasons. In 'Evolution'. (Ed. G. R. de Beer.) pp. 161-177. (Clarendon Press: Oxford, UK.)

Beehner, J. C., Onderdonk, D. A., Alberts, S. C., and Altmann, J. (2006). The ecology of conception and pregnancy failure in wild baboons. Behavioral Ecology 17, 741-750. | CrossRef (http://dx.doi.org/10.1093/beheco/arl006) | (OpenURL BaseURL)

Bercovitch, F. B., Bashaw, M. J., Penny, C. G., and Rieches, R. G. (2004). Maternal investment in captive giraffes. Journal of Mammalogy 85, 428-431. | CrossRef (http://dx.doi.org/10.1644/1545-1542(2004)085<0428:MIICG>2.0.CO;2) | (OpenURL BaseURL)

Berger, J. (1992). Facilitation of reproductive synchrony by gestation adjustment in gregarious mammals: a new hypothesis. Ecology 73, 323-329.

| CrossRef (http://dx.doi.org/10.2307/1938743) | (OpenURL BaseURL) 
Bolker, B. IVI., Brooks, IV. L., Clark, C. J., Geange, S. WV., Poulsen, J. K., Stevens, IV. H. H., and White, J. S. S. (2009). Generalized linear mixed models: a practical guide for ecology and evolution. Trends in Ecology \& Evolution 24, 127-135.

| CrossRef (http://dx.doi.org/10.1016/j.tree.2008.10.008) | (OpenURL BaseURL)

Bonenfant, C., Gaillard, J.-M., Klein, F., and Hamann, J. L. (2005). Can we use the young: female ratio to infer ungulate population dynamics? An empirical test using red deer Cervus elaphus as a model. Journal of Applied Ecology 42, 361-370.

| CrossRef (http://dx.doi.org/10.1111/j.1365-2664.2005.01008.x) | (OpenURL BaseURL)

Boshe, J. I. (1981). Reproductive ecology of the warthog Pahrcochoerus aethiopicus and its significance for management in the eastern Selous Game Reserve, Tanzania. Biological Conservation 20, 37-44.

| CrossRef (http://dx.doi.org/10.1016/0006-3207(81)90059-8) | (OpenURL BaseURL)

Boutton, T. W., Tieszen, L. L., and Imbamba, S. K. (1988a). Seasonal changes in the nutrient of East African grassland vegetation. African Journal of Ecology 26, 103-115.

| CrossRef (http://dx.doi.org/10.1111/j.1365-2028.1988.tb00961.x) |

(OpenURL BaseURL)

Boutton, T. W., Tieszen, L. L., and Imbamba, S. K. (1988b). Biomass dynamics of grassland vegetation in Kenya. African Journal of Ecology 26, 89-101.

| CrossRef (http://dx.doi.org/10.1111/j.1365-2028.1988.tb00960.x) |

(OpenURL BaseURL)

Bowyer, R. T. (1991). Timing of parturition and lactation in southern mule deer. Journal of Mammalogy 72, 138-145.

| CrossRef (http://dx.doi.org/10.2307/1381988) | (OpenURL BaseURL)

Bradshaw, W. E., and Holzapfel, C. M. (2007). Evolution of animal photoperiodism. Annual Review of Ecology Evolution and Systematics 38, 1-25.

| CrossRef (http://dx.doi.org/10.1146/annurev.ecolsys.37.091305.110115) |

(OpenURL BaseURL)

Bro-Jørgensen, J. (2001). Lek-breeding in topi antelopes (Damaliscus lunatus). Ph.D. Thesis, University College London.

Bronson, F. H. (1985). Mammalian reproduction: an ecological perspective. Biology of Reproduction 32, 1-26.

| CrossRef (http://dx.doi.org/10.1095/biolreprod32.1.1) | CAS

(http://chemport.cas.org/cgi-bin/sdcgi?

$\mathrm{APP}=\mathrm{ftslink} \&$ action=reflink \&origin=csiro\&version $=1.0 \&$ pissn $=1035-$

3712\&pyear=2014\&coi=1:STN:280:DyaL2M7itlShsQ\%3D\%3D\&md5=406ce09ae56e38b900176882770d8fcf) |

PubMed (http://www.ncbi.nlm.nih.gov/pubmed?

$\underline{\mathrm{cmd}=\text { Retrieve\&list uids=3882162\&dopt=Abstract) }}$ | (OpenURL BaseURL)

Bronson, F. H. (2009). Climate change and seasonal reproduction in mammals.

Philosophical Transactions of the Royal Society of London. Series B, Biological Sciences 364,

3331-3340. 
| CrossRef (http://dx.doi.org/10.1098/rstb.2009.0140) | CAS (http://chemport.cas.org/cgibin/sdcgi?APP=ftslink\&action=reflink\&origin=csiro\&version=1.0\&pissn=1035-

3712\&pyear=2014\&coi=1:STN:280:DC\%2BD1 MnpsFamtw\%3D\%3D\&md5=77cdd608401163b4ec4b214c04dafb20) | PubMed (http://www.ncbi.nlm.nih.gov/pubmed?

cmd=Retrieve\&list uids=19833645\&dopt=Abstract) | (OpenURL BaseURL)

Bunnell, F. L. (1982). The lambing period of mountain sheep: synthesis, hypotheses, and tests. Canadian Journal of Zoology 60, 1-14.

| CrossRef (http://dx.doi.org/10.1139/z82-001) | (OpenURL BaseURL)

Burthe, S., Butler, A., Searle, K. R., Hall, S. J. G., Thackeray, S. J., and Wanless, S. (2011). Demographic consequences of increased winter births in a large aseasonally breeding mammal (Bos taurus) in response to climate change. Journal of Animal Ecology 80, 11341144.

| CrossRef (http://dx.doi.org/10.1111/j.1365-2656.2011.01865.x) | PubMed (http://www.ncbi.nlm.nih.gov/pubmed? $\underline{\mathrm{cmd}=\text { Retrieve\&list uids=21668894\&dopt=Abstract) | (OpenURL BaseURL) }}$

Clements, M. N., Clutton-Brock, T. H., Albon, D. A., Pemberton, J. M., and Kruuk, L. E. B. (2011). Gestation length variation in a wild ungulate. Functional Ecology 25, 691-703. | CrossRef (http://dx.doi.org/10.1111/j.1365-2435.2010.01812.x) | (OpenURL BaseURL)

Clutton-Brock, T. H., Guinness, F. E., and Albon, S. D. (1982). 'Red Deer: Behaviour and Ecology of Two Sexes.' (University of Chicago Press: Chicago, IL.)

Clutton-Brock, T. H., Major, M., Albon, S. D., and Guinness, F. E. (1987). Early development and population dynamics in red deer. I. Density-dependent effects on juvenile survival. Journal of Animal Ecology 56, 53-67.

| CrossRef (http://dx.doi.org/10.2307/4799) | (OpenURL BaseURL)

Clutton-Brock, T. H., Albon, S. D., and Guinness, F. E. (1989). Fitness costs of gestation and lactation in wild mammals. Nature 337, 260-262.

| CrossRef (http://dx.doi.org/10.1038/337260a0) | CAS (http://chemport.cas.org/cgibin/sdcgi?APP=ftslink\&action=reflink\&origin=csiro\&version=1.0\&pissn=10353712\&pyear=2014\&coi=1:STN:280:DyaL1M\%2FpslaksA\%3D\%3D\&md5=dfe01360424ce00118a25b1e1c0eeab7) | PubMed (http://www.ncbi.nlm.nih.gov/pubmed? $\underline{\mathrm{cmd}=\text { Retrieve\&list uids=2911365\&dopt=Abstract) }}$ | (OpenURL BaseURL)

Cook, J. G., Quinlan, L. J., Irwin, L. L., Bryant, L. D., Riggs, R. A., and Thomas, J. W. (1996). Nutrition-growth relations of elk calves during late summer and fall. The Journal of Wildlife Management 60, 528-541.

| CrossRef (http://dx.doi.org/10.2307/3802070) | (OpenURL BaseURL)

Cook, R. C., Murray, D. L., Cook, J. G., Zager, P., and Monfort, S. L. (2001). Nutritional influences on breeding dynamics in elk. Canadian Journal of Zoology 79, 845-853. | CrossRef (http://dx.doi.org/10.1139/z01-050) | (OpenURL BaseURL)

Cook, J. G., Johnson, B. K., Cook, R. C., Riggs, R. A., Delcurto, T., Bryant, L. D., and Irwin, L. L. (2004). Effects of summer-autumn nutrition and parturition date on reproduction and 
survival of elk. Wildlife Monographs 155, 1-61. (OpenURL BaseURL)

Côté, S.D., and Festa-Bianchet, M. (2001). Birthdate, mass and survival in mountain kids: effects of maternal characteristic and forage quality. Oecologia 127, 230-238.

| CrossRef (http://dx.doi.org/10.1007/s004420000584) | PubMed

(http://www.ncbi.nlm.nih.gov/pubmed?

$\underline{\mathrm{cmd}=\text { Retrieve\&list uids=24577654\&dopt=Abstract) | (OpenURL BaseURL) }}$

Cumming, D. H. (1975). 'A Field Study of the Ecology and Behaviour of Warthog. Vol. 7.'

(Trustees of the National Museums and Monuments of Rhodesia: Salisbury, Rhodesia.)

Deshmukh, I. K. (1984). A common relationship between precipitation and grassland peak biomass for East and southern Africa. African Journal of Ecology 22, 181-186.

| CrossRef (http://dx.doi.org/10.1111/j.1365-2028.1984.tb00693.x) |

(OpenURL BaseURL)

du Plessis, S. S. (1972). 'Ecology of Blesbok with Special Reference to Productivity.' Wildlife Monographs. No. 30. (The Wildlife Society: Washington, DC.)

Dublin, H. T. (1994). Kenya: the 1993 record drought. In 'Gnusletter 13, Nos 1 and 2'. (Ed. R. D. Estes) pp. 14-15. (Antelope Specialist Group, The World Conservation Union:

Peterborough, $\mathrm{NH}$.)

Duncan, P. (1975). Topi and their food supply. Ph.D. Thesis, University of Nairobi, Kenya.

Dunham, K. M., and Murray, M. G. (1982). The fat reserves of impala, Aepyceros melampus. African Journal of Ecology 20, 81-87.

| CrossRef (http://dx.doi.org/10.1111/j.1365-2028.1982.tb00278.x) |

(OpenURL BaseURL)

Estes, R. D. (1976). The significance of breeding synchrony in the wildebeest. East African Wildlife Journal 14, 135-152.

| CrossRef (http://dx.doi.org/10.1111/j.1365-2028.1976.tb00158.x) |

(OpenURL BaseURL)

Estes, R. D. (1991). 'The Behavior Guide to African Mammals.' (University of California Press: Los Angeles, CA.)

Estes, R. D., Atwood, J. L., and Estes, A. B. (2006). Downward trends in Ngorongoro Crater ungulate populations 1986-2005: conservation concerns and the need for ecological research. Biological Conservation 131, 106-120.

| CrossRef (http://dx.doi.org/10.1016/j.biocon.2006.02.009) | (OpenURL BaseURL)

Fairall, N. (1968). The reproductive seasons of some mammals in the Kruger National Park. Zoologica Africana 3, 180-210. (OpenURL BaseURL)

Fairall, N. (1983). Production parameters of the impala, Aepyceros melampus. South African Journal of Animal Science 13, 176-179. (OpenURL BaseURL) 
Festa-Bianchet, M., Jorgenson, J. T., and Reale, D. (2000). Early development, adult mass, and reproductive success in bighorn sheep. Behavioral Ecology 11, 633-639.

| CrossRef (http://dx.doi.org/10.1093/beheco/11.6.633) | (OpenURL BaseURL)

Foster, J. B., and Dagg, A. I. (1972). Notes on the ecology of the giraffe. East African Wildlife Journal 10, 1-16.

| CrossRef (http://dx.doi.org/10.1111/j.1365-2028.1972.tb00855.x) |

(OpenURL BaseURL)

Gaillard, J. M., Delorme, D., and Julien, J. M. (1993a). Effects of cohort, sex and birth date on body development of roe deer (Capreolus capreolus) fawns. Oecologia 94, 57-61.

| CrossRef (http://dx.doi.org/10.1007/BF00317301) | (OpenURL BaseURL)

Gaillard, J. M., Delorme, D., Julien, J. M., and Tatin, D. (1993b). Timing and synchrony of births in roe deer. Journal of Mammalogy 74, 738-744.

| CrossRef (http://dx.doi.org/10.2307/1382296) | (OpenURL BaseURL)

Georgiadis, N., and McNaughton, S. J. (1990). Elemental and fibre contents of savanna grasses: variation with grazing, soil type, season and species. Journal of Applied Ecology 27, 623-634.

| CrossRef (http://dx.doi.org/10.2307/2404307) | CAS (http://chemport.cas.org/cgibin/sdcgi?APP=ftslink\&action=reflink\&origin=csiro\&version=1.0\&pissn=10353712\&pyear=2014\&coi=1:CAS:528:DyaK3MXhs1akt7s\%3D\&md5=b537e255e154a14f53b71a5bf4c9f638) | (OpenURL BaseURL)

Georgiadis, N., Hack, M., and Turpin, K. (2003). The influence of rainfall on zebra population dynamics: implications for management. Journal of Applied Ecology 40, 125136.

| CrossRef (http://dx.doi.org/10.1046/j.1365-2664.2003.00796.x) | (OpenURL BaseURL)

Gogan, P. J. P., Podruzny, K. M., Olexa, E. M., Pac, H. I., and Frey, K. L. (2005). Yellowstone bison fetal development and phenology of parturition. The Journal of Wildlife Management 69, 1716-1730.

| CrossRef (http://dx.doi.org/10.2193/0022-541X(2005)69[1716:YBFDAP]2.0.CO;2) | (OpenURL BaseURL)

Gosling, L. M. (1969). Parturition and related behavior in Coke's hartebeest, Alcelaphus buselaphus cokei Günther. Journal of Reproduction and Fertility. Supplement 6, 265-286. (OpenURL BaseURL)

Green, W. C. H., and Rothstein, A. (1993). Persistent influences of birth date on dominance, growth and reproductive success in bison. Journal of Zoology 230, 177-186. | CrossRef (http://dx.doi.org/10.1111/j.1469-7998.1993.tb02680.x) | (OpenURL BaseURL)

Grimsdell, J. J. R. (1973). Reproduction in the African buffalo (Syncerus caffer) in western Uganda. Journal of Reproduction and Fertility. Supplement 19, 303-318.

I CAS (http://chemport.cas.org/cgi-bin/sdcgi? $\underline{A P P=f t s l i n k \& a c t i o n=r e f l i n k \& o r i g i n=c s i r o \& v e r s i o n=1.0 \& p i s s n=1035-}$ 
Guinness, F. E., Clutton-Brock, T. H., and Albon, S. D. (1978). Factors affecting calf mortality in red deer (Cervus elaphus). Journal of Animal Ecology 47, 817-832.

| CrossRef (http://dx.doi.org/10.2307/3673) | (OpenURL BaseURL)

Gunn, R. G., and Doney, J. M. (1975). The interaction of nutrition and physical condition at mating on ovulation rate and early embryo mortality in Scottish blackface ewes. Journal of Agricultural Science (Cambridge) 85, 465-470.

| CrossRef (http://dx.doi.org/10.1017/S0021859600062341) | (OpenURL BaseURL)

Hall-Martin, A. J., Skinner, J. D., and Van Dyk, J. M. (1975). Reproduction in the giraffe in relation to some environmental factors. East African Wildlife Journal 13, 237-248.

| CrossRef (http://dx.doi.org/10.1111/j.1365-2028.1975.tb00137.x) |

(OpenURL BaseURL)

Hass, C. C. (1997). Seasonality of births in bighorn sheep. Journal of Mammalogy 78, 12511260.

| CrossRef (http://dx.doi.org/10.2307/1383068) | (OpenURL BaseURL)

Jönsson, K. I. (1997). Capital and income breeding as alternative tactics of resource use in reproduction. Oikos 78, 57-66.

| CrossRef (http://dx.doi.org/10.2307/3545800) | (OpenURL BaseURL)

Jorgenson, J. T., Festa-Bianchet, M., Lucherini, M., and Wishart, W. D. (1993). Effects of body size, population density, and maternal characteristics on age at first reproduction in bighorn ewes. Canadian Journal of Zoology 71, 2509-2517.

| CrossRef (http://dx.doi.org/10.1139/z93-344) | (OpenURL BaseURL)

Keech, M. A., Bowyer, R. T., Ver Hoef, J. M., Boertje, R. D., Dale, B. W., and Stephenson, R. (2000). Life-history consequences of maternal condition in Alaskan moose. The Journal of Wildlife Management 64, 450-462.

| CrossRef (http://dx.doi.org/10.2307/3803243) | (OpenURL BaseURL)

Kieltie, R. A. (1988). Gestation as a constraint on the evolution of seasonal breeding in mammals. In 'Evolution of Life Histories of Mammals. Theory and Pattern'. (Ed. M. S. Boyce.) pp. 257-289. (Yale University Press: New Haven, CT.)

Kim, Y., Choi, Y.-K., and Emery, S. (2013). A logistic regression with multiple random effects: a simulation study of estimation methods and statistical packages. The American Statistician 67, 171-182.

| CrossRef (http://dx.doi.org/10.1080/00031305.2013.817357) | (OpenURL BaseURL)

Kingdon, A. (1989). 'East African Mammals: an Atlas of Evolution in Africa. Vol. III. Part D (Bovids).' (University of Chicago Press: Chicago, IL.)

Kingdon, J. (1997). 'The Kingdon Field Guide to African Mammals.' (Academic Press:

London.) 
Langman, V. A. (1977). Cow-calf relationships in giraffe (Giraffa camelopardalis giraffa). Zeitschrift für Tierpsychologie 43, 264-286. (OpenURL BaseURL)

Langvatn, R., Mysterud, A., Stenseth, N. C., and Yoccoz, N. G. (2004). Timing and synchrony of ovulation in red deer constrained by short northern summers. American Naturalist 163, 763-772.

| CrossRef (http://dx.doi.org/10.1086/383594) | PubMed (http://www.ncbi.nlm.nih.gov/pubmed? $\underline{\mathrm{cmd}=\text { Retrieve\&list uids=15122493\&dopt=Abstract) | (OpenURL BaseURL) }}$

Leuthold, W., and Leuthold, B. M. (1975). Temporal patterns of reproduction in ungulates of Tsavo East National Park, Kenya. East African Wildlife Journal 13, 159-169.

| CrossRef (http://dx.doi.org/10.1111/j.1365-2028.1975.tb00133.x) | (OpenURL BaseURL)

Loudon, A. S. I., Darroch, A. D., and Milne, J. A. (1984). The lactation performance of red deer on hill and improved species pastures. Journal of Agricultural Science 102, 149-158. | CrossRef (http://dx.doi.org/10.1017/S0021859600041587) | (OpenURL BaseURL)

Moe, S. R., Rutina, L. P., and du Toit, J. T. (2007). Trade-off between resource seasonality and predation risk explains reproductive chronology in impala. Journal of Zoology 273, 237-243.

| CrossRef (http://dx.doi.org/10.1111/j.1469-7998.2007.00319.x) | (OpenURL BaseURL)

Moss, C. J. (2001). The demography of an African elephant (Loxodonta africana) population in Amboseli, Kenya. Journal of Zoology 255, 145-156.

| CrossRef (http://dx.doi.org/10.1017/S0952836901001212) | (OpenURL BaseURL)

Moyes, K., Nussey, D. H., Clements, M. N., Guinness, F. E., Morris, A., Morris, S., Pemberton, J. M., Kruuk, L. E. B., and Clutton-Brock, T. H. (2011). Advancing breeding phenology in response to environmental change in a wild red deer population. Global Change Biology 17, 2455-2469.

| CrossRef (http://dx.doi.org/10.1111/j.1365-2486.2010.02382.x) | (OpenURL BaseURL)

Murray, M. G. (1982). The rut of impala: aspects of seasonal mating under tropical conditions. Zetischrift für Tierpsychology 59, 319-337.

| CrossRef (http://dx.doi.org/10.1111/j.1439-0310.1982.tb00345.x) | (OpenURL BaseURL)

Nefdt, R. J. C. (1996). Reproductive seasonality in Kafue lechwe antelope. Journal of Zoology 239, 155-166.

| CrossRef (http://dx.doi.org/10.1111/j.1469-7998.1996.tb05443.x) |

(OpenURL BaseURL)

Novellie, P. (1986). Relationships between rainfall, population density and the size of the bontebok lamb crop in the Bontebok National Park. South African Journal of Wildlife Research 16, 39-46. (OpenURL BaseURL) 
Oftedal, O. T. (1985). Pregnancy and lactation. In 'Bioenergetics of Wild Herbivores'. (Ed. R. J. Hudson and R. G. White.) pp. 215-238. (CRC Press: Boca Raton, FL.)

Ogutu, J. O., Bhola, N., Piepho, H.-P., and Reid, R. (2006). Efficiency of strip- and linetransect surveys of African savanna mammals. Journal of Zoology 269, 149-160.

(OpenURL BaseURL)

Ogutu, J. O., Piepho, H.-P., Dublin, H. T., Bhola, N., and Reid, R. S. (2008a). El NiñoSouthern Oscillation, rainfall, temperature and normalised difference vegetation index fluctuations in the Mara-Serengeti ecosystem. African Journal of Ecology 46, 132-143. | CrossRef (http://dx.doi.org/10.1111/j.1365-2028.2007.00821.x) | (OpenURL BaseURL)

Ogutu, J. O., Piepho, H.-P., Dublin, H. T., Bhola, N., and Reid, R. S. (2008b). Rainfall influences on ungulate population abundance in the Mara-Serengeti ecosystem. Journal of Animal Ecology 77, 814-829.

| CrossRef (http://dx.doi.org/10.1111/j.1365-2656.2008.01392.x) | CAS (http://chemport.cas.org/cgi-bin/sdcgi? $\underline{\mathrm{APP}}=\mathrm{ftslink} \&$ action $=$ reflink \&origin $=\mathrm{csiro} \&$ version $=1.0 \&$ pissn $=1035-$ 3712\&pyear=2014\&coi=1:STN:280:DC\%2BD1cvgsFynug\%3D\%3D\&md5=c46969a9525582191775d3353a658e4d) | PubMed (http://www.ncbi.nlm.nih.gov/pubmed? $\underline{\mathrm{cmd}=\text { Retrieve\&list uids=18422558\&dopt=Abstract) | (OpenURL BaseURL) }}$

Ogutu, J. O., Piepho, H.-P., Dublin, H. T., Bhola, N., and Reid, R. S. (2009). Dynamics of Mara-Serengeti ungulates in relation to land use changes. Journal of Zoology 278, 1-14. | CrossRef (http://dx.doi.org/10.1111/j.1469-7998.2008.00536.x) | (OpenURL BaseURL)

Ogutu, J. O., Piepho, H.-P., Dublin, H. T., Bhola, N., and Reid, R. S. (2010). Rainfall extremes explain interannual shifts in timing and synchrony of calving in topi and warthog. Population Ecology 52, 89-102. | CrossRef (http://dx.doi.org/10.1007/s10144-009-0163-3) | (OpenURL BaseURL)

Ogutu, J. O., Piepho, H.-P., Dublin, H. T., Bhola, N., and Reid, R. S. (2011). Dynamics of births and juvenile recruitment in Mara-Serengeti ungulates in relation to climatic and land use changes. Population Ecology 53, 195-213.

| CrossRef (http://dx.doi.org/10.1007/s10144-010-0223-8) | (OpenURL BaseURL)

Owen-Smith, R. N. (1988). 'Mega Herbivores: the Influence of Very Large Body Size on Ecology.' (Cambridge University Press: Cambridge, UK.)

Owen-Smith, N. (2002). 'Adaptive Herbivore Ecology. From Resources to Populations in Variable Environments.' (Cambridge University Press: Cambridge, UK.)

Owen-Smith, N. (2008). The comparative population dynamics of browsing and grazing ungulates. In 'The Ecology of Grazing and Browsing Ungulates'. (Eds I. J. Gordon and H. H. T. Prins.) pp. 149-177. (Spinger Verlag: Berlin.)

Owen-Smith, N., and Ogutu, J. O. (2013). Controls over reproductive phenology among ungulates: allometry and tropical-temperate contrasts. Ecography 36, 256-263. 
Parker, K. L., Barboza, P. S., and Gillingham, M. P. (2009). Nutrition integrates environmental responses of ungulates. Functional Ecology 23, 57-69.

| CrossRef (http://dx.doi.org/10.1111/j.1365-2435.2009.01528.x) | (OpenURL BaseURL)

Penzhorn, B. I. (1985). Reproductive characteristics of a free-ranging population of Cape Mountain zebra (Equus zebra zebra). Journal of Reproduction and Fertility 73, 51-57. | CrossRef (http://dx.doi.org/10.1530/jrf.0.0730051) | CAS (http://chemport.cas.org/cgi-

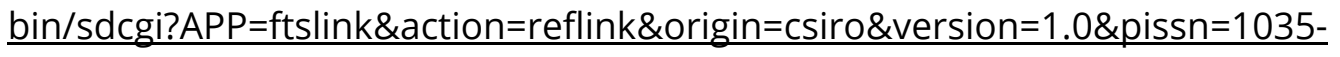
3712\&pyear=2014\&coi=1:STN:280:DyaL2M7gslyhtw\%3D\%3D\&md5=f8ad53ef926f680b2d8a75c5da4ecff8) | (OpenURL BaseURL)

Percival, A. B. (1928). 'A Game Ranger on Safari.' (Nisbet and Co: London.)

Piepho, H. P., and Ogutu, J. O. (2007). Simple state space models in a mixed model framework. The American Statistician 61, 224-232.

| CrossRef (http://dx.doi.org/10.1198/000313007X220426) | (OpenURL BaseURL)

Post, E. (2003). Timing of reproduction in large mammals. In 'Phenology: an Integrative Environemental Science'. (Ed. M. D. Schwartz.) pp. 437-449. (Kluwer Academic Publishers: Dordrecht, The Netherlands.)

Post, E., and Forchhammer, M. C. (2008). Climate change reduces reproductive success of an Arctic herbivore through trophic mismatch. Transactions of the Royal Society Series $B$ 363, 2369-2375. (OpenURL BaseURL)

Post, E., and Stenseth, N. C. (1999). Climatic variability, plant phenology, and northern ungulates. Ecology 80, 1322-1339.

| CrossRef (http://dx.doi.org/10.1890/0012-9658(1999)080[1322:CVPPAN]2.0.CO;2) | (OpenURL BaseURL)

Post, E., Bøving, P. S., Perdersen, C., and MacArthur, M. A. (2003). Synchrony between caribou calving and plant phenology in depredated and non-depredated populations. Canadian Journal of Zoology 81, 1709-1714.

| CrossRef (http://dx.doi.org/10.1139/z03-172) | (OpenURL BaseURL)

Post, E., Pedersen, C., Wilmers, C. C., and Forchhammer, M. C. (2008). Warming, plant phenology and the spatial dimension of trophic mismatch for large herbivores.

Proceedings of the Royal Society. Series B 275, 2005-2013.

| CrossRef (http://dx.doi.org/10.1098/rspb.2008.0463) | (OpenURL BaseURL)

Pratt, D. M., and Anderson, V. H. (1982). Population, distribution, and behaviour of giraffe in the Arusha National Park. Tanzania Journal of Natural History 16, 481-489.

| CrossRef (http://dx.doi.org/10.1080/00222938200770381) | (OpenURL BaseURL)

Prins, H. H. T. (1988). Plant phenology patterns in Lake Manyara National Park, Tanzania. Journal of Biogeography 15, 465-480.

| CrossRef (http://dx.doi.org/10.2307/2845276) | (OpenURL BaseURL) 
Prins, H. H. T. (1996). 'Ecology and Behaviour of the African Buffalo: Social Inequality and Decision Making.' (Chapman and Hall: New York.)

Prins, H. H. T., and Beekman, J. H. (1989). A balanced diet as a goal for grazing: the food of the Manyara buffalo. African Journal of Ecology 27, 241-259.

| CrossRef (http://dx.doi.org/10.1111/j.1365-2028.1989.tb01017.x) |

(OpenURL BaseURL)

Rutberg, A. T. (1987). Adaptive hypotheses of birth synchrony in ruminants: an interspecific test. American Naturalist 130, 692-710.

| CrossRef (http://dx.doi.org/10.1086/284739) | (OpenURL BaseURL)

Rutherford, M. C. (1980). Annual plant production-precipitation relations in arid and semi-arid regions. South African Journal of Science 76, 53-56. (OpenURL BaseURL)

Ryan, S. J., Knechtel, C. V., and Getz, W. M. (2007). Ecological cues, gestation length, and birth timing in African buffalo (Syncerus caffer). Behavioral Ecology 18, 635-644.

| CrossRef (http://dx.doi.org/10.1093/beheco/arm028) | (OpenURL BaseURL)

Sadleir, R. M. F. S. (1969). 'The Ecology of Reproduction in Wild and Domestic Animals.' (Methuen and Co.: London.)

SAS Institute (2013). 'SAS System for Windows. Version 9.3.' (SAS Institute: Cary, NC.)

Sidney, O. J. (1965). The past and present distribution of some African ungulates.

Transactions of the Zoological Society of London 30,1-397. (OpenURL BaseURL)

Simon, N. (1962). 'Between the Sunlight and the Thunder: The Wild Life of Kenya.' (Collins: London.)

Sinclair, A. R. E., and Duncan, P. (1972). Indices of condition in tropical ruminants. East African Journal of Ecology 10, 143-149.

| CrossRef (http://dx.doi.org/10.1111/j.1365-2028.1972.tb00868.x) |

(OpenURL BaseURL)

Sinclair, A. R. E., Mduma, S. A. R., and Arcese, P. (2000). What determines phenology and synchrony of ungulate breeding in Serengeti? Ecology 81, 2100-2111.

| CrossRef (http://dx.doi.org/10.1890/0012-9658(2000)081[2100:WDPASO]2.0.CO;2) |

(OpenURL BaseURL)

Skinner, J. D., and Chimimba, C. T. (2005). 'The Mammals of the Southern African Subregion.' (Cambridge University Press: Cambridge, UK.)

Skinner, J. D., Moss, D. G., and Skinner, D. C. (2002). Inherent seasonality in the breeding seasons of African mammals: evidence from captive breeding. Transactions of the Royal Society of South Africa 57, 25-34.

| CrossRef (http://dx.doi.org/10.1080/00359190209520524) | (OpenURL BaseURL) 


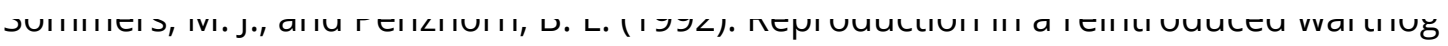
population in the eastern Cape Province. South African Journal of Wildlife Research 22, 5760. (OpenURL BaseURL)

Spinage, C. A. (1973). The role of photoperiodism in the seasonal breeding of tropical African ungulates. Mammal Review 3, 71-83.

| CrossRef (http://dx.doi.org/10.1111/j.1365-2907.1973.tb00174.x) | (OpenURL BaseURL)

Stanley-Price, M. R. (1974). The feeding ecology of Coke's hartebeest, Alcelaphus buselaphus cokei Günther in Kenya. D.Phil. Thesis, University of Oxford, UK.

Stephens, P. A., Boyd, I. L., McNamara, J. M., and Houston, A. I. (2009). Capital breeding and income breeding: their meaning, measurement and worth. Ecolgy 90, 2057-2067. | CrossRef (http://dx.doi.org/10.1890/08-1369.1) | (OpenURL BaseURL)

Talbot, L. M., and Talbot, M. H. (1963). 'The Wildebeest in Western Maasialand, East Africa.' Wildlife Monographs No. 12. (The Wildlife Society: Washington, DC.)

Testa, J. W. (2002). Does predation on neonates inherently select for earlier births? Journal of Mammalogy 83, 699-706.

| CrossRef (http://dx.doi.org/10.1644/1545-1542(2002)083<0699:DPONIS>2.0.CO;2) | (OpenURL BaseURL)

Thomas, D. C. (1982). The relationship between fertility and fat reserve in Peary caribou. Canadian Journal of Zoology 60, 597-602.

| CrossRef (http://dx.doi.org/10.1139/z82-089) | (OpenURL BaseURL)

Verme, L. J. (1965). Reproduction studies on penned whitetailed deer. The Journal of Wildlife Management 29, 74-79.

| CrossRef (http://dx.doi.org/10.2307/3798633) | (OpenURL BaseURL)

Walker, B. H., Emslie, R. H., Owen-Smith, R. N., and Scholes, R. J. (1987). To cull or not to cull: lessons from a southern African drought. Journal of Applied Ecology 24, 381-401.

| CrossRef (http://dx.doi.org/10.2307/2403882) | (OpenURL BaseURL)

Western, D. (1979). Size, life history and ecology in mammals. African Journal of Ecology 17, 185-204.

| CrossRef (http://dx.doi.org/10.1111/j.1365-2028.1979.tb00256.x) |

(OpenURL BaseURL)

Wittemyer, G., Rasmussen, H. B., and Douglas-Hamilton, I. (2007a). Breeding phenology in relation to NDVI variability in free-ranging African elephant. Ecography 30, 42-50.

| CrossRef (http://dx.doi.org/10.1111/j.0906-7590.2007.04900.x) | (OpenURL BaseURL)

Wittemyer, G., Ganswindt, A., and Hodges, K. (2007b). The impact of ecological variability on the reproductive endocrinology of wild female African elephants. Hormones and

Behavior 51, 346-354.

| CrossRef (http://dx.doi.org/10.1016/j.yhbeh.2006.12.013) | CAS

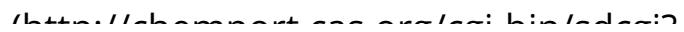


IIllp://crleminur l.cds.urg/cyi-NIII/sucgi!

$\underline{A P P}=$ ftslink\&action=reflink\&origin=csiro\&version=1.0\&pissn=1035-

3712\&pyear=2014\&coi=1:CAS:528:DC\%2BD2sXis10ktr4\%3D\&md5=0d938d7e3124632bbdd90e051a09bb19) |

PubMed (http://www.ncbi.nlm.nih.gov/pubmed?

$\underline{\mathrm{cmd}=\text { Retrieve\&list uids=17320085\&dopt=Abstract) | (OpenURL BaseURL) }}$

Zerbe, P., Marcus, C., Codron, D., Lackey, L. B., Rensch, E., Streich, J. W., Hatt, J.-M., and Müller, D. W. H. (2012). Reproductive seasonality in captive wild ruminants: implications

for biogeographical, photoperiodic control, and life history. Biological Reviews of the Cambridge Philosophical Society 87, 965-990.

| CrossRef (http://dx.doi.org/10.1111/j.1469-185X.2012.00238.x) | PubMed

(http://www.ncbi.nlm.nih.gov/pubmed?

$\underline{\mathrm{cmd}=\text { Retrieve\&list uids=22780447\&dopt=Abstract) | (OpenURL BaseURL) }}$

\section{JOURNAL HOME}

About the Journal

Editorial Structure

Publishing Policies

Contacts

\section{CONTENT}

Online Early

Current Issue

lust Accepted

All Issues

Special Issues

Sample Issue

\section{FOR AUTHORS}

General Information

Scope

Submit Article

Author Instructions

Open Access

\section{FOR REFEREES}

$\underline{\text { Referee Guidelines }}$

Review an Article 


\section{FOR SUBSCRIBERS}

Subscription Prices

Customer Service

Print Publication Dates

Library Recommendation

\section{FOR ADVERTISERS}

\section{e-Alerts}

Subscribe to our Email Alert (?nid=25\&aid=685) or $\mathrm{A}$

(http://www.publish.csiro.au/RSS Feed/CSIRO Publishing Recent WR.xml) feeds for the latest journal papers.

\section{CSIRO Wildlife Research}

All volumes of CSIRO Wildlife Research (http://www.publish.csiro.au/nid/144.htm?nid=145\&aid=112) are online and available to subscribers of Wildlife Research.

\section{LINKS}

About Us (/aboutus)

Contact Us (/aboutus/contactus)

Help (/aboutus/help)

Workshops (/workshops)

Sciencelmage (http://www.scienceimage.csiro.au/)

BROWSE BY SUBJECT

Animals (/Animals) 
Built Environment (/BuiltEnvironment)

Food \& Agriculture (/FoodAndAgriculture)

Gardening \& Horticulture (/GardeningAndHorticulture)

Health (/Health)

Marine \& Freshwater (/MarineAndFreshwater)

Natural Environment (/NaturalEnvironment)

Physical Sciences (/PhysicalSciences)

Plants (/Plants)

Science in Society (/ScienceinSociety)

\section{CONNECT WITH US}

(https://www.facebook.com/pages/CSIRO-PUBLISHING/70534682887)

(https://twitter.com/CSIROPublishing) in (https://www.linkedin.com/company/csiro-publishing)

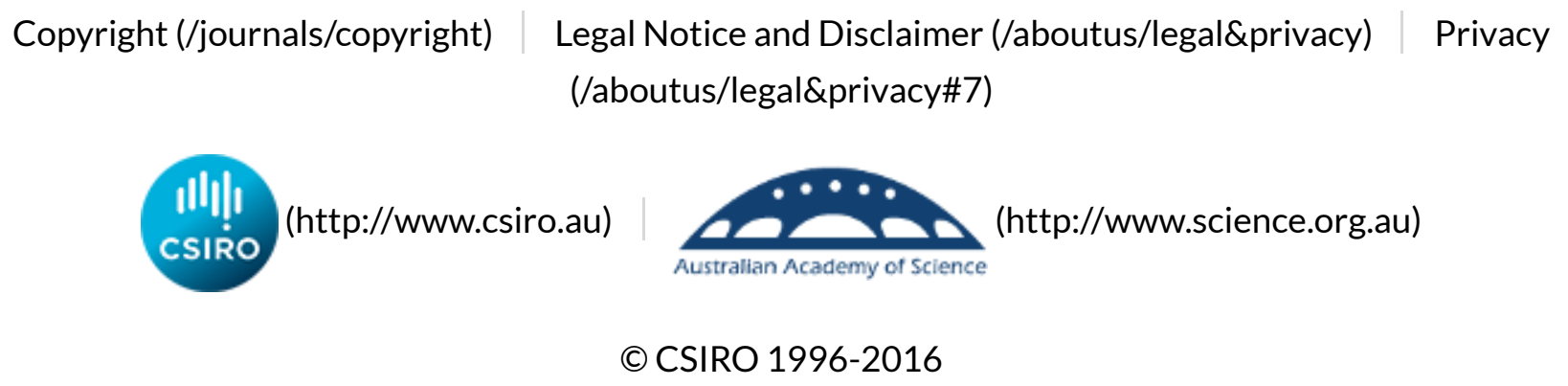

